\title{
TINJAUAN TERHADAP STRATEGI PEMASARAN PADA TABUNGAN HAJI DALAM AKAD MUDHARABAH (STUDI KASUS BANK SYARIAH MANDIRI KCP SUDIRMAN, BOGOR)
}

\author{
Nuryadi Akbar \\ Universitas Ibn Khaldun \\ Jl. K.H. Soleh Iskandar Km. 2 Kedung Badak, Tanah Sareal, Bogor, Jawa Barat \\ E-mail: nuryadiakbar321@gmail.com
}

\begin{abstract}
Abstrak : Strategi pemasaran yang dilakukan oleh BSM dan penerapan analisis swot pada strategi pemasaran pada produk tabungan haji. Penelitian ini dilakukan untuk mengatahui strategi pemasaran dan penerapan analisis swot pada produk tabungan haji di BSM KCP Sudirman, Bogor. Metode yang digunakan yaitu kualitatif, dan data sekunder yang bersumber dari naskah, catatan, dokumen dll, serta analisa data yang digunakan reduksi data. Hasil yang diperoleh dari penelitian ini, bahwa strategi pemasaran yang dilakukan oleh BSM KCP Sudirman, Bogor mengguanakan target pasar yang dituju yaitu segmentation khusus secara segi daerah atau wilayah, segi usia, dan segi status nasabah. Selain itu BSM menggunakan bauran pemasaran yang mengandung unsur 4P, yaitu strategi produk, harga, saluran distribusi, dan promosi. Dalam strategi promosi menggunakan promosi berupa periklanan, penjualan pribadi, promosi penjualan dan publisitas. Hasil analisis di atas, dapat disimpulkan bahwa kekuatan memiliki poin lebih besar daripada kelemahan, sehingga peluang untuk Produk Tabungan Haji lebih besar dari pada ancamannya.
\end{abstract}

Kata kunci :,Strategi, Pemasaran, tabungan Haji, Mudharabah

Abstract : The marketing strategy carried out by BSM and the application of SWOT analysis to the marketing strategy on the Hajj savings product. This research was conducted to find out the marketing strategies and application of swot analysis on haji savings products at BSM KCP Sudirman, Bogor. The method used is qualitative, and secondary data sourced from manuscripts, notes, documents, etc., and data analysis used for data reduction. The results obtained from this study, that the marketing strategy carried out by BSM KCP Sudirman, Bogor uses the intended target market, specifically segmentation in terms of region or region, age, and customer status. In addition, BSM uses a marketing mix that contains 4P elements, namely product strategy, price, distribution channels and promotions. In promotion strategies use promotions in the form of advertising, personal sales, sales promotions and publicity. The results of the analysis above, it can be concluded that strength has more points than weaknesses, so the opportunity for Haji Savings Products is greater than the threat.

Keywords: Strategy, Marketing, Hajj savings, Mudharabah

\section{PENDAHULUAN}

Bank syariah berkembang pesat di dunia, sejak didirikannya Islamic development bank (IDB) Sejak tahun

1975, bank syariah telah mengembangkan dananya seperti bank konvensional lainnya dan telah

Received: 2018-12-21| Reviced: 2019-02-07| Accepted: 2019-02-12

Indexed : DOAJ, Garuda, Crossref, Google Scholar | DOI : https://doi.org/10.29313/amwaluna.v3i1.4260 
menjadi penghimpun dan penyaluran dana ummat islam untuk kepentingan yang berkaitan dengan ibadah, seperti dana zakat, infaq dan shodaqoh.

Maupun bermuamalah, seperti simpanan al-wadi'ah dan mudharabah.

Bank merupakan suatu lembaga keuangan yang memiliki peran penting dan strategis dalam perekonomian suatu negara, yaitu dalam lalu lintas pembayaran dan penyediaan dana untuk pembiayaan pembangunan. Secara tradisional dinyatakan, bahwa kegiatan utama bank adalah menghimpun dana dari masyarakat dan menyalurkan kembali dalam bentuk kredit.

Bank sebagai penghimpun dana dan penyalur dana pada masyarakat ini dapat ditemukan dalam rumusan defenisi bank yang dimuat dalam Pasal 1 angka (2) Undang-Undang No. 7 Tahun 1992 yang telah diubah dengan Undang-Undang No. 10 Tahun 1998 Tentang Perbankan, yang selanjutnya disebut dengan UU Perbankan yang menyatakan "Bank adalah badan usaha yang menghimpun dana dari masyarakat dalam bentuk simpanan dan menyalurkannya kepada masyarakat dalam bentuk kredit atau dalam bentuk bentuk lainnya dalam rangka meningkatkan taraf hidup masyarakat".

Dalam Undang-Undang nomor 21 tahun 2008 tentang perbankan syariah, bahwa perbankan syariah merupakan segala sesuatu yang menyangkut tentang bank syariah dan unit usaha syariah, mencakup kelembagaan, kegiatan usaha serta cara dan proses melaksanakan kegiatan usahanya. Bank syariah adalah bank yang menjalankan kegiatan usahanya berdasarkan prinsip syariah dan menurut jenisnya terdiri atas bank umum syariah (BUS) dan bank pembiayaan rakyat syariah (BPRS).

Salah satu sarana yang mempunyai peranan strategis dalam kegiatan ekonomi adalah perbankan. Peran strategis tersebut disebabkan oleh fungsi perbankan sebagai finansial intermediary, yaitu sebagai salah satu wahana yang dapat menghimpun dana dan menyalurkan dana masyarakat secara efisien dan efektif. Perbankan syariah pada dasarnya merupakan perkembangan dari konsep ekonomi islam, terutama dalam bidang keuangan. Perbankan syariah dalam peristilahan internasional dikenal sebagai islamic banking. 
Pengumpulan dana dalam istilah perbankan syariah lebih dikenal dengan pendanaan (funding), sedangkan penyaluran dana disebut dengan pembiayaan (financing). Produk pendanaan yang umum ada didalam sistem perbankan syariah maupun konvensional salah satunya adalah tabungan.Tabungan merupakan suatu produk dimana seseorang menyimpan sejumlah uangnya di suatu lembaga keuangan dan orang tersebut sewaktu-waktu dapat mengambil kembali uang yang telah disimpannya.

Perbedaan yang mendasar dalam mekanisme kerja penghimpunan dana syariah terletak pada tidak adanya bunga yang lazim digunakan oleh bank konvensional dalam memeberikan keuntungan kepada nasabah. Ketentuan tentang haramnya menggunakan mekanisme Bunga bagi bank syariah difatwakan oleh dewan syariah nasional (DSN) tahun 2000 nomor 1 tentang giro, nomor 2 tentang tabungan dan nomor 3 deposito. Berdasakan fatwa DSN dalam ekonomi Islam, syarat untuk melakukan suatu transaksi adalah kesepakatan antara kedua belah pihak yang disebut dengan akad. Tercantum dalam UU No. 21 tahun 2008 tentang Perbankan Syariah pada pasal 1 ayat 13 bahwa Akad adalah kesepakatan tertulis antara Bank Syariah atau UUS dan pihak lain yang memuat adanya hak dan kewajiban bagi masing-masing pihak sesuai dengan Prinsip Syariah.

Di Indonesia hampir semua bank syariah menerapkan prinsip mudharabah untuk menghimpun dana. Akad mudharabah adalah suatu perjanjian dimana seseorang memberikan hartanya kepada orang lain berdasarkan prinsip dagang, dan keuntungan yang diperoleh akan dibagi berdasarkan pembagian yang disetujui oleh para pihak.

Allah $S W T$, berfirman:

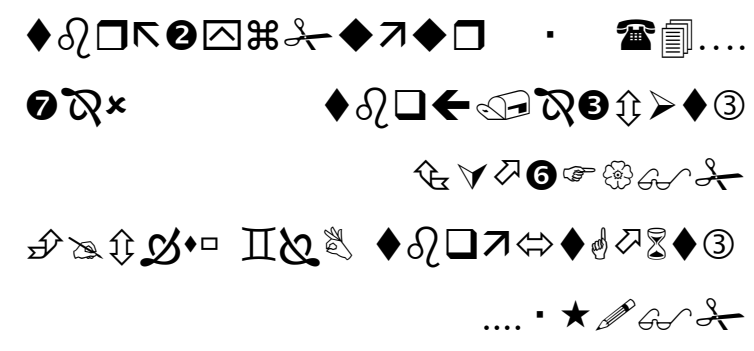

Artinya: “...dan orang-orang yang berjalan di muka bumi mencari sebagian karunia Allah...."(al-Qur'an surat al-muzzammil;20)

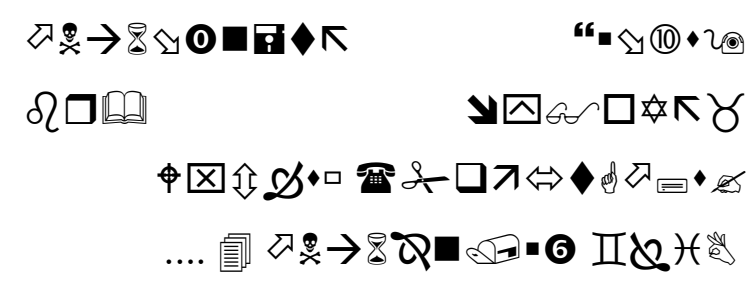

Artinya: "Tidak ada dosa bagimu untuk mencari karunia (rezki hasil 
perniagaan) dari Tuhanmu...."(al-

Qur'an surat al-baqarah;198)

Kedua ayat diatas tersebut, secara umum mengandung kebolehan akad mudharabah, yang secara bekerjasama mencari rezeki yang ditebarkan allah SWT dimuka bumi.

Dalam pasal 1 angka 5 peraturan bank Indonesia nomor 7/46/PBI/2005 mudharabah adalah penanaman dana dari pihak dana (shahibul maal) kepada pengelola dana (mudharib) untuk melakukan kegiatan usaha tertentu, dengan pembagian menggunakan bagi untung dan rugi (profit and loss sharing) atau metode bagi pendapatan (revenue sharing) antara kedua belah pihak berdasarkan nisbah yang telah disepakati sebelumnya.

Akad produk ini sesuai dengan prinsip syariah karena adanya nisbah atau bagi hasil. Salah satu produk tabungan dalam perbankan syariah adalah tabungan haji. Tabungan haji merupakan produk dimana seseorang menyimpan dananya di bank yang kemudian akan dipergunakannya untuk ibadah haji. Produk ini dikhususkan bagi masyarakat muslim indonesia yang berencana menunaikan ibadah haji. Ibadah haji termasuk rukun islam yang ke 5, Ibadah haji merupakan suatu kewajiban bagi umat islam yang sudah mampu secara fisik dan materi.

Dalam perkembangannya akad mudharabah terasa kurang populer dikalangan masyarakat. Hanya sebagian masyarakat mengetahui tentang apa yang dimaksud akad mudharabah, bagaimana prosedur untuk menikmati akad mudharabah dilingkungan perbankan syariah. Sehingga perlunya dilakukan pengenalan lebih lanjut kepada masyarakat akan produk-produk perbankan syariah dalam perbaikan ekonomi dan kemaslahatan umat.

Dalam mensosialisasikan suatu produk maka di tidak terlepas dengan strategi pemasaran, sreategi pemasaran yang di terapkan harus ditinjau dan di kembangkan sesuai dengan perkembangan pasar dan lingkungan pasar tersebut, dengan demikian strategi pemasaran harus memberikan gambaran yang jelas dan terarah tentang apa yang dilakukan dan menggunakan setiap kesempatan atau peluang pada beberapa sasaran pasar.

Strategi merupakan serangkaian rencana besar yang menggambarkan bagaimana sebuah perusahaan harus beroperasi untuk mencapai tujuannya. Sedangkan strategi pemasaran merupakan proses pemasaran yang 
mencakup beberapa hal analisis dan kesempatan-kesempatan, pemilihan, sasaran-sasaran, pengembangan strategi, perumusan rencana, implementasi, serta pengawasan.

Metode penelitian digunakan oleh penulis yaitu pendekatan kualitatif. Dalam penelitian kualitatif, Penelitian ini dilakukan di Bank Syariah Mandiri KCP Sudirman Bogor.

Teknik pengambilan data menggunakan jenis pengambilan data yaitu wawancara, Observasi, dan Dokumentasi.

Teknik analisis data menggunakan teknik reduksi data, penyajian data dan Menarik kesimpulan atau verifikasi (Prastowo, 2011).

\section{PEMBAHASAN}

\section{A. KONSEP STRATEGI PEMASARAN}

\section{Pengertian Strategi}

Istilah strategi berasal dari kata yunani strategia yaitu stratos yang berarti militer dan $a g$ artinya memimpin, yang berararti seni atau ilmu untuk menjadi seorang jendral (Fandy, 2008:3). Pada awalnya startegi diartikan generalship, sesuatu yang dilakukan oleh para jendral dalam membuat rencana untuk menaklukan musuh dan memenangkan peperangan. Setiawan dan Zulkiefli berpendapat, tidaklah mengherankan jika pada awalnya strategi selalu dikaitkan dengan siasat yang disusun untuk menghadapi perang pemasaran, dan memenangkan pertarungan. namun demikian, makna strategi berubah pada tahun 1950-an.

Strategi pemasaran dimaksudkan untuk meningkatkan pertukaran dan mempertahankan perusahaan pada kondisi pasar yang stabil. Strategi pemasaran yang menyeluruh, terpadu dan menyatu dibidang pemasaran yang memberikan paduan tentang kegiatan yang akan dijalankan untuk tercapainya tujuan pemasaran. Bank Syariah Mandiri menetapkan strategi pemasaran untuk menjual produknya yang tujuannya adalah untuk mencapai tujuan bank yakni menjaring masyarakat untuk hijrah menginvestasikan dananya.

\section{Pengertian Pemasaran}

Tingkat persaingan dalam dunia usaha menuntut setiap perusahaan untuk dapat lebih 
mengunggulkan

segala

kemampuannya dalam memasarkan

produk dan jasa yang

ditawarkan.Setiap kegiatan tersebut

memerlukan sebuah konsep

pemasaran yang mendasar agar

efektif dan efisien sesuai dengan

orientasi perusahaan terhadap pasar

(Buchori dan Donni, 2009:257).

\section{Pengertian Strategi Pemasaran}

Strategi pemasaran adalah suatu rencana yang memungkinkan suatu organisasi untuk membuat pengguanaan yang terbaik tentang sumber daya dan keuntungan untuk mempertemukan hasil sasarannya.Strategi pemasaran terdiri dari dua unsur, pertama. Analisa dan pemilihan dari suatu target pasar. Kedua. Pemilihan dan menciptakan suatu bauran pemasaran (suatu kombinasi produk, harga, distribusi, dan promosi) yang dikembangkan untuk memenuhi target pasar tertentu.

Pemasaran

syariah

mempunyai karakteristik,

Hermanwan menguraikan

karakteristik dari marketing syariah, terdiri atas beberapa unsur, yaitu: a. Theistis (robbaniyah)

Ketuhanan yaitu keyakinan yang bulat, bahwa semua kegiatan manusia selalu dibawah pengawasan ilahi, semua insan harus berprilaku sebaik mungkin, tidak berprilaku licik, menipu, mencuri milik orang lain dan suka memakan harta orang lain dengan cara yang bathil.

b. Etis (akhaqiah)

Etis artinya semua perilaku berjalan diatas norma etika yang berlaku umum. Etika adalah hati, jika seorang pembisnis mempunyai perilaku yang buruk, maka dalam berniagapun akan melakukan kecurangan, seperti mengoplos barang, menimbun barang, mengambil harta orang lain dengan jalan yang bathil. Hal ini menjadi panduan bagi marketer syariah selalu memelihara setiap tutur kata, perilaku dalam hubungan bisnis, konsumen, atau saingan dalam berbisnis.

c. Realistis (al-waaqiyyah)

Realistis artinya sesuai dengan kenyataan, semua transaksi yang harus dilalukan harus 
berdasarkan realita serta tidak menutupi kekurangan produk yang dipasarkan.

d. Humanistis (al-insaniyyah)

Humanitis artinya berperi kemanusiaan, seorang marketer harus memiliki sifat kemanusiaan yang terjaga dan terpelihara. Dan dalam melakukan kegiatan pemasaran dengan batas-batas kewajaran manusia.

\section{Bauran Pemasaran (Marketing}

Mix)

Konsep pemasaran mempunyai seperangkat alat pemasaran yang dapat dikendalikan, yaitu dengan bauran pemasaran (Marketing mix) (Nur Rianto, 2010:14).

Bauran pemasaran adalah kesepakatan alat pemasaran yang digunakan perusahaan untuk terus menerus mencapai tujuan pemasarannya dipasar sasaran (Kotler, 2008).

Kotler mendefinisikan bauran pemasaran (Marketing mix) adalah seperangkat alat pemasaran faktor yang dapat dikendalikan produk, price, promosions, place yang dipadukan oleh perusahaan untuk menghasilkan respon yang diinginkan dalam pasar sasaran.

Dalam bauran pemasaran ada empat (4) faktor, yang biasa disebut konsep empat (P) product, price, place, promotion.

a. Product (produk)

b. Price (harga)

c. Place (saluran distribusi)

d. Promotion (promosi)

Adapun kegiatan yang termasuk dalam aktivitas promosi adalah advertising, personal selling, sales promotion, publicity:

1) Periklanan (advertising)

Iklan adalah sarana promosi yang digunakan oleh perusahan dan segala sesuatu produk yang dihasilakan oleh perusahaan. Informasi yang diberikan adalah nama produk, manfaat produk, harga produk, serta keuntungan produk. Tujuan promosi dengan cara periklanan adalah berusaha untuk menarik dan mempengaruhi nasabah lama dan calon nasabah baru. 
2) Penjualan pribadi (personal selling)

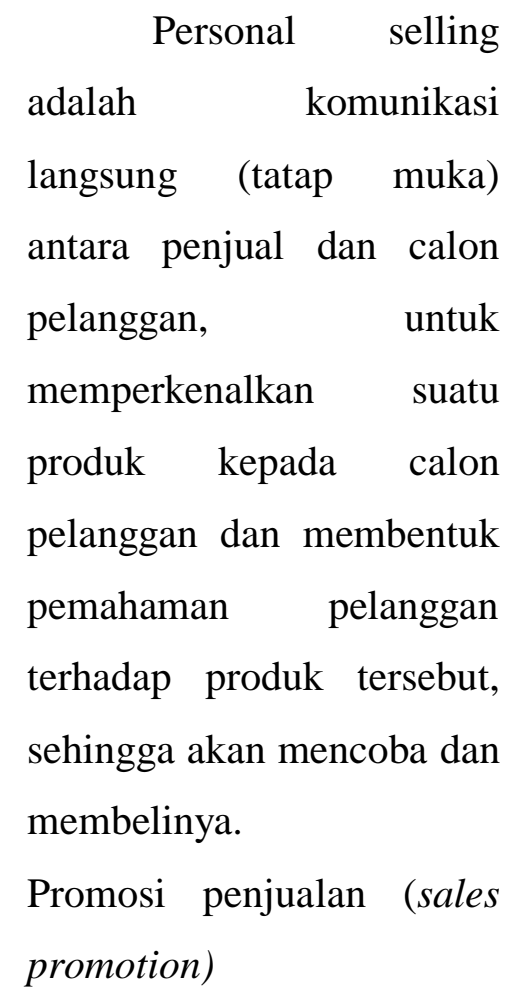

Promosi penjualan adalah untuk meningkatkan penjualan atau meningkatkan jumlah nasabah.Promosi penjualan dilakukan untuk menarik nasabah untuk segera membeli setiap produk atau jasa yang

ditawarkan.Kegiatan penjualan yang bersifat jangka pendek dan tidak dilakukan secara berulang (Kotler, 2008).

4) Publisitas (publisity)

$$
\text { Publisitas adalah }
$$

bentuk penyajian dan penyebaran ide barang dan jasa secara non personal, yang mana orang atau organisasi yang diuntungkan tidak membayar.Publistas merupakan manfaatan nilainlai berita yang terkandung dalam suatu produk membantu citra produk yang bersangkutan dibandingkan dengan iklan, publisitas mempunyai krediblitas yang lebih baik, karena pembenaran baik langsung maupun tidak langsung (Fandy :228).

\section{KONSEP TABUNGAN HAJI}

\section{AKAD MUDHARABAH}

\section{Pengertian Tabungan}

Tabungan merupakan jenis simpanan yang sangat dikenal oleh masyarakat, karena sejak sekolah dasar anak-anak sekolah sudah dikenalkan dengan tabungan, meskipun masih bersifat menabung disekolah.Hal ini secara tidak langsung pihak sekolah memperkenalkan kepada anak-anak untuk berhemat dan menabung.Meskipun tabungan tersebut sifatnya bukan tabungan 
yang diterapkan dibank, namun istilah menabung sudah diperkenalkan kepada kita dari sejak kecil (Ismail, 2010:67).

\section{Pengertian Tabungan Haji}

Tabungan haji adalah suatu bentuk pelayanan dari perbankan yang bertujuan untuk mempermudah masyarakat dalam merencankan tabungan untuk menunaikan ibadah haji. Bank syariah sebagai lembaga keuangan yang berbasis syariah berupaya untuk menghimpun dana masyarakat yang ingin menunaikan ibadah haji memberikan beberapa bentuk pelayanan yang sesuai dengan syariah. Baik dalam segi akad maupun bentuk operasional lainnya.

\section{Pengertian Akad}

Secara terminology bahasa akad berarti ikatan atau simpul (alrabth), al-ahd (janji). Menurutistilah akad adalah ikatan antara ijab dan kabul yang sesuai dengan syara' dan menimbulkan akibat hukum bagi objeknya (Ibdalsyah dan Hendri, 2014:51).

\section{Pengertian Mudharabah}

$$
\text { Mudharabah adalah }
$$

kerjasama yang dilakukan oleh dua orang atau lebih dimana pemilik modal menyerahkan modalnya untuk dikelola oleh pekerja, dan keuntungan dibagi berdasarkan kesepakatan.Dalam konsep mudharabah ini dasarnya adalah berbagi baik bagi untung ataupun berbagi didalam kerugian desebut dengan loss and profit sharing.

Dalam akad mudharabah tentunya terdapat rukun dan syarat yang harus ditaati.rukun dari akad mudharabah (Ascarya, 2008) yaitu: a. Pelaku akad, yaitu shahibul maal (pemodal) adalah pihak yang memiliki modal tetapi tidak bias berbisnis, dan muharib (pengelola) adalah pihak yang pandai berbisnis, tetpai tidak memiliki modal.

b. Objek akad, yaitu modal (maal), kerja (dharabah) dan keuntungan (ribh)

c. Shighat yaitu ijab dan Kabul.

Sedangkan syarat dalam akad mudharabah yang harus dipenuhi terdiri dari syarat modal dan syarat keuntungan, syarat modal (Usman, 2009) yaitu:

a. Modal harus diketahui jumlah dan jenisnya.

b. Modal dapat berbentuk uang atau barang yang bernilai. Jika 
modal diberikan dalam bentuk aset, aset tersebut harus bernilai dalam waktu akad.

c. Modal tidak dapat berbentuk piutang dan harus dibayarkan kepada mudharib, baik secara bertahap atau tidak, sesuai kesepakatan dalam akad.

\section{Macam-Macam Mudharabah}

Salah satu prinsip yang digunakan bank syariah dalam memobilisasi dana yaitu dengan menggunakan prinsip mudharabah, tujuan dari mudharabah adalah kerjasama antara pemilik dana (shahibul maal) dan pengelola dana (mudharib) dalam hal ini bank syariah (Antonio, 2001).

Secara garis besar mudharabah terbagi menajdi dua jenis, yatu sebagai berikut:

\section{a. Mudharabah Mutlaqah}

Mudharabah mutlaqah adalah akad kerjasama diamana pemodal tidak mensyaratkan kepada pengelola untuk melakukan jenis usaha tertentu.

Jenis usaha yang akan dijalankan oleh mudharib secara mutlak diputuskan oleh mudharib yang dirasa sesuai sehingga disebut mudharabah yang tidak terikat atau terbatas.
Hal yang tidak dibolehkan oleh pengelola tanpa seizin pemodal antara lain meminjam modal, meminjamkan modal, dan memudharabahkan lagi dengan orang lain.

Dalam skema mudharabah mutlaqah terdapat beberapa hal yang sangat berbeda secara fundamental dalam hal nature of relationship between bank and customers pada bank konvensional.

a. Penabung atau deposan dibank syariah adalah investor dengan sepenuhnya bermakna investor. Bukan leader atau creditor bagi bank seperti halnya dibank umum. Dengan demikian secara prinsip, penabung dan deposan entitled untuk risk dan return dari hasil usaha bank.

b. Bank memiliki dua fungsi yaitu kepada deposan atau penabung, ia bertindak sebagai pengelola (mudharib), sedangkan kepada dunia usaha, bank berfungsi sebagai pemilik 
dana (shahibul maal).

Dengan demikian bank

harus sharing risk dan

return.

c. Dunia usaha berfungsi

sebagai pengguna dan

pengelola dana yang harus

berbagi hasil dengan

pemilik dana, yaitu bank.

Dalam pengembangannya,

nasabah pengguna dana

dapat menjalin hubungan

dengan bank dalam bentuk

jual beli, sewa, dan free

based services.

\section{b. Mudharabah Muqayyadah}

Mudharabah

muqayyadah adalah akad kerjasama dimana shohibul maal menetapkan syarat tertentu yang harus dipatuhi oleh mudharib, baik mengenai tempat usaha, tujuan, maupun jenis usaha (Antonio:150).

Dalam investasi dengan menggunakan konsep mudharabah muqayyadah, pihak bank terikat dengan ketentuan-ketentuan yang telah ditetapkan oleh shahibul maal, misalnya;

- Jenis investasi.

- Waktu dan tempat.
Produk special investment based on restricted mudharabah ini sangat sesuai dengan special hight networth individuals atau company yang memiiki kecenderungan investasi khusus.

Disamping itu, special investment merupakan modus funding dan financing, sekaligus yang sangat cocok pada krisis dan sektor perbankan mengalami kerugian yang menyeluruh, dengan special investment, investor tertentu tidak perlu menanggung overhead bank yang terlalu besar karena seluruh dananya masuk ke proyek khusus dengan return dan cost yang yang dihitung khusus.

\section{B. HASIL PENELITIAN}

1. Penerapan Analisis SWOT Pada Strategi Pemasaran Tabungan Haji Mabrur BSM

Untuk menghadapi banyaknya persaingan di bidang jasa keuangan khususnya perbankkan, adanya hal-hal yang perlu dipertimbangkan sebelum menerapkan strategi pemasaran produk antara lain diawali dengan melakukan 
analisis swot, dimana ia menilai empat hal, yaitu: Kekuatan (strengths), kelemahan (weaknesses), peluang (opportunities), dan ancaman (threats).

Berdasarkan penelitian yang dilakukan oleh penulis, dapat diketahui analisis swot yang dilakukam oleh Bank Syariah Mandiri KCP Sudirman, Bogor. Hasil yang diperoleh dari analisis kekuatan, kelemahan, peluang dan ancaman dalam strategi pemasaran tabungan Haji Mabrur di Bank Syariah Mandiri KCP Sudirman, Bogor anatara lain sebagai berikut:

a. Kekuatan (strengths)

Kekuatan menggambarkan keunggulan kompetitif yang dimiliki perusahaan untuk membantu perusahaan dalam melayani pelanggannya dan mencapai tujuannya.Bank Syariah Mandiri KCP Sudirman Bogor memiliki kekuatan yang besar. Dikarnakan Bank Syariah Mandiri KCP Sudirman, Bogor berada di tengah pusat kota Bogor, tepatnya berdekapan dengan perkantoran, pusat perbelanjaan, balai kota Bogor, dan lainnya. Dimana lokasinya sangat strategis dan mudah dijangkau oleh masyarakat Bogor dan sekitarnya.
Berdasarkan peraturan pemerintah mengenai pelaksanaan ibadah haji harus melalui perbankan syariah juga menjadi kekuatan Bank Syariah Mandiri KCP Sudirman, Bogor dalam memasarkan produk Tabungan Haji Mabrur. Kekuatan yang lainnya adalah bekerjasama dengan Kemenag yaitu online langsung SISKOHAT (Sistem Komputerisasi Haji Terpadu) dan bekerja sama dengan Kelompok Bimbingan Ibadah Haji (KBIH).

Bank Syariah Mandiri juga memiliki SDM yang berkualiatas dengan dibekali pendidikan dan pelatihan yang mumpuni.agar marketing lebih mengatahui segala sesuatu tentang produk-produk yang ada di Bank Syariah Mandiri.

b. Kelemahan (weaknesses)

Kelemahan merupakan keterbatasan internal dan faktor situasional yang dapat menghalangi performa perusahaan dalam memasarkan produk tabungan Haji Mabrur.Kelemahan pada Bank Syariah Mandiri KCP Sudirman, Bogor terdapat pada sedikitnya jumlah karyawan.Hal ini dapat menghambat pemasaran tabungan haji mabrur tersebut. 
c. Peluang (opportunities)

Peluang merupakan faktor yang berasal dari lingkungan yang dapat membantu perusahaan dalam memasarkan produk tabungan Haji Mabrur.Dalam memasarkan produk tabungan haji mabrur, Berdasarkan analisa yang dilakukan oleh penulis, peluang Bank Syariah Mandiri KCP Sudirman, Bogor terletak pada status Bank Syariah Mandiri. Dikarnakan Bank Syariah Mandiri tersebut memiliki kantor cabang yang tersebar di kota maupun kabupaten diseluruh Indonesia dan bank syariah mandiri memilki citra yang baik dimata masyarakat.

Semua orang muslim pasti ingin melaksanakan ibadah haji dan umrah sehingga produk tabungan Haji mempunyai prospek yang sangat bagus untuk BSM karena tingginya tingkat populasi penduduk beragama islam di Indonesia khususnya kota Bogor dan sekitarnya. Hal ini menjadi peluang yang sangat bagus pada pemasaran produk tabungan haji mabrur yang dimiliki Bank Syariah Mandiri.

Peluang yang dimiliki BSM selanjutnya adalah lamanya daftar tunggu haji (whating list), semakin lamanya daftar tunggu untuk haji maka semakin sadarnya masyarakat muslim untuk merencanakan ibadah haji dari sejak dini yaitu dengan membuka tabungan haji mabrur yan miliki Bank Syariah Mandiri.

d. Ancaman (threats)

Ancaman merupakan faktor pada lingkungan eksternal yang tidak menguntungkan untuk pihak bank.Ancaman dalam pemasaran produk tabungan haji mabrur tersebut adalah persaingan antar bank-bank syariah lainnya di wilayah Bogor yang juga memiliki produk tabungan haji.Selain itu hal yang harus diperhatikan adalah kegiatan promosi pesaing dalam memasarkan produk tabungan haji merupakan suatu ancaman untuk terus bisa bersaing untuk mendapatkan banyak nasabah.

$$
\text { Ancaman selanjutnya }
$$

adalah Semakin inovatif produk, fitur, serta fasilitas yang ditawarkan oleh bank Syariah lainnya yang dilengkapi dengan teknologi canggih membuat semakin ketatnya persaingan pemasaran produk tabungan haji. 
Berdasarkan hasil uraian membuat tabel yang berisikan poinkekuatan, kelemahan, peluang dan poin dalam analisis tersebut.

ancaman di atas, dalam hal ini penulis

Tabel 1

Analisis Swot Strategi Pemasaran

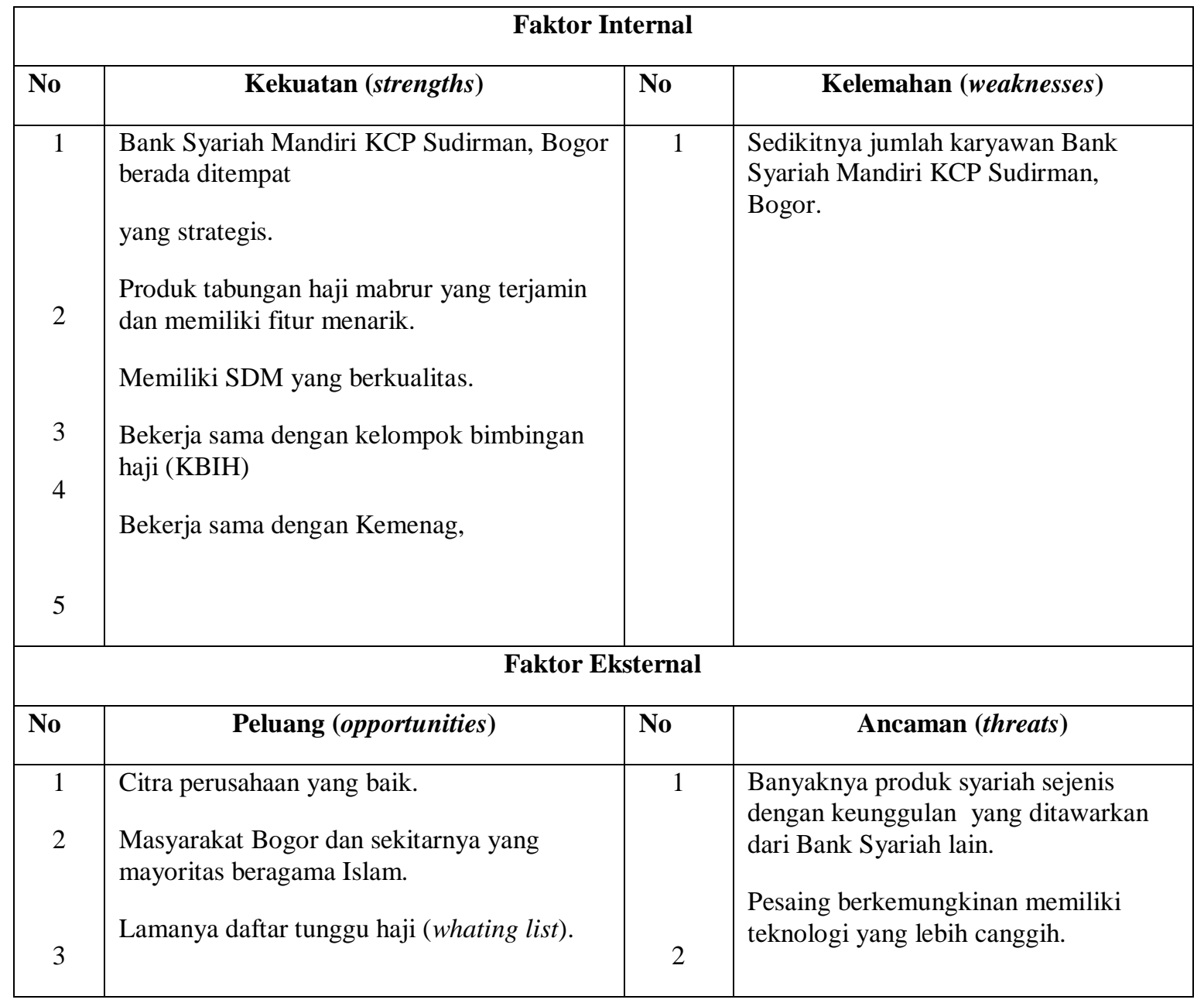

Dari hasil analisis di atas, dapat disimpulkan bahwa kekuatan memiliki poin lebih besar dari pada kelemahan, sehingga peluang untuk Produk Tabungan Haji Mabrur lebih besar dari pada ancamannya.

\section{Analisa Penulis}

Ada beberapa aspek yang dilakukan Bank Syariah Mandiri dalam melakukan strategi pemasaran pada produk tabungan haji mudharabah 
tersebut. Dalam pemilihan target pasar, yaitu: ${ }^{1}$

a. Bank Syariah Mandiri melakukan segmentation. Segmentasi pasar yang dilakukan sudah tepat, karna BSM mensegemntasikan secara khusus, yaitu dari segi daerah atau wilayah, segi usia, dan dari segi status nasabah tersebut. Sehingga pemasaran BSM menjadi lebih fokus terhadap target pasar yang dituju.

b. Bank Syariah Mandiri melakukan targeting dalam pemilihan target pasarnya. Berdasarkan analisa yang dilakukan penulis bahwa target pasar yang dilakukan BSM yaitu dengan mentargetkan masyarakat yang beragama islam, karna sebagian besar masyarakat Indonesia beragama islam.

c. Pemilihan target pasar yang dilakukan Bank Syariah Mandiri adalah positioning. Bank Syariah Mandiri mensosialisasikan dirinya sebagai mitra bisnis yang amanah dan maslahah, sebagai lembaga keuangan yang tugas pokoknya mengumpulkan dana dari masyarakat dan menyalurkannya kembali kepada masyarakat. Menurut analisa penulis, Bank

${ }^{1}$ Hasil wawancara, Ruslia Nengsih, Bagian Marketing, pada Tanggal 20 Oktober 2018. Online ISSN : 2540-8402 | Print ISSN : 2540-8399
Syariah Mandiri merupakan solusi terbaik untuk memberikan berbagai fasilitas produk dan jasa. dalam proses yang cepat, praktis dan menentramkan serta jangka waktu tertentu yang fleksibel, khususnya pada produk tabungan haji mabrur BSM.

Bauran pemasaran (marketing mix) yang dilakukan Bank Syariah Mandiri pada produk tabungan haji mabrur yaitu: Product (produk), Price (harga), Place (tempat), Promotion (promosi). Strategi pemasaran pada Bank Syariah Mandiri KCP Sudirman, Bogor dapat dilihat dari unsur-unsur diatas dan berlandaskan prinsip syari'ah.Strategi pemasaran yang berdasarkan prinsip syari'ah dinilai memberikan pandangan yang lebih baik dikarenakan didalamnya terkandung nilai-nilai ibadah dan sosial yang memberikan kedamaian bagi yang melaksanakan kegiatan pemasaran tersebut. $^{2}$

Bahwa pada dasarnya setiap lembaga atau perusahaan memerlukan strategi yang efektif, efisien dan baik dalam memasarkan produk yang dimilikinya. Bauran pemasaran yang dimaksud yaitu :

1) Product (produk)

${ }^{2}$ Hasil wawancara, Ruslia Nengsih, Bagian Marketing, pada Tanggal 20 Oktober 2018. 
Produk merupakan suatu benda atau pelayanan jasa yang ditawarkan oleh BSM untuk mendapatkan perhatian permintaan yang dapat memenuhi keinginan dan kebutuhan nasabah.

Produk yang dimiki oleh BSM pada tabungan haji tersebut adalah tabungan haji mabrur produk tersebut menggunakan prinsip mudharabah muthlaqah yaitu tabungan yang menggunakan sistem bagi hasil atau nisbah, BSM sebagai pihak pengelola berhak menggunakan modal tersebut. Investor atau penabung akan mendapatkan bagi hasil atau nisbah yang yang telah disepakati diawal akad, pembagian nisabah yang berlaku diBSM ialah $15 \%$ untuk nasabah atau investor sedangkan $85 \%$ untuk pihak pengelola atau bank, pihak bank bertanggung jawab atas modal yang telah diinvestasikan. Produk tabungan haji mabrur tersebut memberikan kemudahan kepada nasabahnya serta memberikan rasa aman, terjamin dan online dengan SISKOHAT Kementerian Agama.

Produk yang ditawarkan Bank Syariah Mandiri pada tabungan haji mabrur dalam akad mudharabah sudah berdasarkan prinsip syari'ah. Hal ini berkaitan dengan Fatwa Dewan Nasional Syari'ah No: 02/DSNMUI/IV/2000, yaitu:

Ketentuan

Umum

Tabungan berdasarkan

Mudharabah:

a) Dalam transaksi ini nasabah bertindak sebagai shahibul mal atau pemilik dana, dan bank bertindak sebagai mudharib atau pengelola dana.

b) Dalam kapasitasnya sebagai mudharib, bank dapat melakukan berbagai macam usaha yang tidak bertentangan dengan prinsip syari'ah dan mengembangkannya, termasuk di dalamnya mudharabah dengan pihak lain.

c) Modal harus dinyatakan dengan jumlahnya, dalam bentuk tunai dan bukan piutang.

d) Pembagian keuntungan harus dinyatakan dalam bentuk nisbah dan dituangkan dalam akad pembukaan rekening.

e) Bank sebagai mudharib menutup biaya operasional tabungan dengan menggunakan nisbah keuntungan yang menjadi haknya.

f) Bank tidak diperkenankan mengurangi nisbah keuntungan 
nasabah tanpa persetujuan yang bersangkutan.

2) Price (Harga)

Jika dilihat dari segi harga, menurut analisa penulis harga pada produk Tabungan Haji mabrur tersebut sangat terjangkau untuk semua masyarakat muslim, karena pembukaan rekening pada tabungan haji mabrur BSM hanya Rp 100.000 dan setoran selanjutnya Rp. 100.000, hal ini sangat terjangkau dan tidak memberatkan nasabah.

3) Place (Saluran Distribusi)

Dilihat pada tempat Bank Syariah Mandiri KCP Sudirman, Bogor sangat strategis, dikarenakan alamat Bank Syariah Mandiri KCP Sudirman, Bogor merupakan akses utama menuju pusat kota Bogor dan sangat mudah dijangkau melalui alat transportasi dari berbagai jenis, baik kendaran pribadi maupun umum. Selain itu Bank Syariah Mandiri KCP Sudirman, Bogor sangat dekat dengan pusat perbelanjaan, sekolah, kampus, kantor-kantor maupun lingkungan masyarakat sekitar.Hal ini dapat dijangkau oleh masyarakat tersebut.

4) Promotion (Promosi)
Dalam hal promosi menurut hasil wawancara dengan staf marketing yaitu dengan Ruslia Nengsih, promosi yang dilakukan oleh Bank Syariah Mandiri KCP Sudirman, Bogor dalam memasarkan produk tabungan haji mabrur, maka Bank Syariah Mandiri KCP Sudirman melakukan strategi promosi sebagai berikut: ${ }^{3}$

a) Periklanan yang dilakukan BSM yaitu dengan mencetak brosur, koran nasioanal atau local, yang didalamnya berisikan tentang produk Bank Syariah Mandiri seperti syarat dan ketentuan produk, akad yang digunakan dalam produk tersebut, dan fasilitas dalam produknya, BSM juga membuat spanduk yang dipasang ditempat yang strategis, selanjutnya nasabah bisa mengunjungi website BSM tentang informasi lebih lanjut produkproduk Bank Syariah Mandiri tersebut.

b) Penjualan pribadi ini tidak dilakukan oleh staf marketing atau customer service saja tetapi dilakukan oleh seluruh pegawai Bank Syariah Mandiri, mulai dari security, cleaning service, sampai

${ }^{3}$ Hasil wawancara, Ruslia Nengsih, Bagian Marketing, pada Tanggal 20 Oktober 2018. 
dengan pejabat Bank Syariah

Mandiri tersebut. Hal ini sangat membantu marketing dalam memasarkan produknya serta akan menjadikan keuntungan bank dalam mendapatkan nasabah baru.

c) Promosi penjualan yang diterapkan Bank Syariah Mandiri adalah memberikan cinderamata, pemberian insentif dengan saldo tertentu, hadiah, dan kenangkenangan lainnya kepada nasabah yang setia kepada Bank Syariah Mandiri.

d) Publisitas yang dilakukan Bank Syariah Mandiri mengikuti pameran yang berada di Mall atau departemen store sekitar. Yang bertujuan kegiatan tersebut adalah agar nasabah dapat lebih mengenal Bank Syariah Mandiri, dengan kegiatan tersebut diharapkan agar nasabah selalu mengingat Bank Syariah Mandiri.

\section{III.SIMPULAN}

Dari uaraian, penjelasan dan analisa diatas sebagai hasil penelitian yang berkenaan dengan Tinjauan Strategi Pemasaran Pada Tabungan Haji Dalam Akad mudharabah, maka penulis mengambil simpulan, sebagai berikut pertama, Strategi pemasaran pada Tabungan Haji Mabrur di Bank Syariah Mandiri, dengan menggunakan pasar yang dituju yaitu: a)Segmentation, Bank Syariah Mandiri segmentasi secara khusus, yaitu segi daerah atau wilayah, segi usia, segi status nasabah. b)Targeting,Bank Syariah Mandiri Mentargetkan dalam tabungan Haji Mabrur tersebut adalah masyarakat yang beragama islam. c)Positioning, Bank Syariah Mandiri mensosialisasikan dirinya sebagai mitra bisnis yang amanah dan maslahah, sebagai lembaga keuangan yang tugas pokoknya mengumpulkan dana dari masyarakat dan menyalurkannya kembali kepada masyarakat.

Selain itu BSM juga menggunakan strategi bauran pemasaran atau marketing mix yang terdiri dari 4 unsur, yaitu: 1)Strategi produk, tabungan haji mabrur yang dimiliki Bank Syariah Mandiri tersebutnasabah akan mendapatkan kemudahan mendapatkan porsi haji, dan telah terhubung langsung dengan Sistem Komputerisasi Haji Terpadu (SISKOHAT). 2)Strategi harga, Bank Syariah Mandiri dalam menetapkan harga tabungan haji mabrur sangat terjangkau, Dengan 
pembukaan rekening hanya $\mathrm{Rp}$. 100.000 dan setoran selanjutnya Rp. 100.000,-. 3)Strategi saluran distribusi, lokasiBank Syariah Mandiri KCP Sudirman, Bogor sangat strategis karna berada dipusat kota Bogor. 4)Strategi promosi, dilakukan oleh Bank Syariah Mandiri KCP Sudirman, Bogor dalam memasarkan produk tabungan haji mabrur, Bank Syariah Mandiri KCP Sudirman melakukan strategi promosi melalui periklanan, penjualan pribadi, promosi penjualan dan publisitas.

Penerapan Analisis Swot pada Strategi Pemasaran Tabungan Haji Mabrur BSM, yaitu: 1)Kekuatan (strengths), terdapat kekuatan dalam pemasaran tabungan haji mabrur, yaitu: Bank Syariah Mandiri KCP Sudirman Bogor berada ditempat yang strategis, produk tabungan haji mabrur yang terjamin dan memiliki fitur menarik, memiliki SDM yang berkualitas.

2)Kelemahan (weaknesses), Kelemahan pada Bank Syariah Mandiri KCP Sudirman, Bogor terdapat pada sedikitnya jumlah karyawan. Hal ini dapat menghambat pemasaran tabungan haji mabrur tersebut. 3)Peluang (opportunities) adanya peluang yang besar dalam pemasaran tabungan haji mabrur yaitu: citra perusahaan yang baik, masyarakat bogor dan sekitarnya yang mayoritas beragama Islam,lamanya daftar tunggu haji (whating list) menjadi salah satu peluang bagi BSM dalam memasarkan produk tabungan haji mabrur tersebut. 4)Ancaman (threats), terdapatnya ancaman pada produk tabungan haji mabrur yaitu: banyaknya produk syariah sejenis dengan keunggulan yang ditawarkan dari Bank Syariah lain, pesaing berkemungkinan memiliki teknologi yang lebih canggih.

\section{Saran-saran}

Berdasarkan hasil pembahasan , maka saran yang diberikan kepada Bank Syariah Mandiri KCP Sudirman, Bogor dalam tinjauan terhadap strategi pemasaran pada tabungan haji dalam akad mudharabah, yaitu: 1) Meningkatkan kualitas produk tabungan haji mabrur dan berinovasi untuk dapat menarik minat masyarakat secara luas dalam menggunakan tabungan haji mabrur 
pada BSM dan tetap berprinsif syariat islam. 2) Meningkatkan kualitas pelayanan kepada nasabah BSM, agar nasabah mendapatkan kenyamanan dan merasa aman dalam menunggu antrian.

\section{DAFTAR PUSTAKA}

Alma, Buchari dan Donni Juni Priansa, Manajemen Bisnis Syariah, Bandung; Alfa Beta, 2009.

Antonio, Muhammad Syafi'i, Bank Syariah Dari Teori ke Praktik. Jakarta; Gema Insani, 2001.

Anwar, Syamsul Hukum Perjanjian Syariah, Jakarta; PT. Raja Grapindo Persada, 2007

Aqwa Naser Daulay, "Faktor-Faktor Yang Berhubungan Dengan Perkembangan Produk Tabungan Haji Perbankan Syariah di Indonesia", Jurnal Human Falah: Vol. 4. No. 1 Januari-Juni 2017.

Ascarya, Akad dan Produk Bank Syariah, Jakarta; PT Grapindo Persada, 2008

Basrowi, dan Suwandi, Memahami Penelitian, Jakarta; Rineka Cipta, 2008.

Dani R, Indriya dan Hayatillah, Hajj dan Umrah, Jakarta; PT. Agro Media Pustaka, 2015.
Eldine, Achyar, Pengantar Bisnis, Jakarta; Direktorat Jendral Perkebunan, 2013.

Fuad, Muhammad, et el, Pengantar Bisnis, Jakarta; PT Gramedia Pustaka Utama, 2005.

Haming, Murdifin dan Mahpud Nurnajamuddin, Managemen Produksi Modern, Jakarta; PT. Bumi Aksara, 2014.

Hamovinsah, Metodologi Penelitian, Jakarta; Universitas Marcu Buana, 2008 .

Ibdalsyah dan Hendri Tanjung, Fiqih Muamalah, Bogor; Azam dunya, 2014.

IBI dan SLPP, Strategi Bisnis Bank Syariah, Jakarta; PT. Gramedia Pustaka Utama, 2015.

Iskandar, Metodologi Penelitian Kualitatif, Jakarta; Gaung Persada, 2009.

Ismail, Manajemen Perbankan dari Teori ke Aplikasi, Jakarta; Kencana, 2010.

Kasmir, Bank dan Lembaga Keuangan Syariah, Jakarta; PT. Raja Grapindo Persada, 2001.

, Bank dan Lembaga Keuangan Lainnya, Jakarta; PT. Raja Grapindo Persada, 2013.

KBBI, Jakarta; PT Gramedia Pustaka Utama, 2008. 
Kotler ,Philip dan AB Susanto,

Manajemen Pemasaran di

Indonesia, Jakarta; Salemba

Empat, 2000.

Martono, Bank dan Lembaga Keuangan

Lain, Jogjakarta; Ekonisa, 2002.

Meloeng J, Lexy, Metodologi Penelitian

Kualitatif, Bandung; Remaja

Rosdakarya, 2011.

Mursid, Muhammad, Manajemen

Pemasaran, Jakarta; PT Bumi

Aksara, 2010.

Nickels, G. William, et el, Pengantar

Bisnis, Jakarta; Edwar Tanujaya, 2011.

Prastowo, Andi, Metode Penelitian Kualitatif, Jogjakarta; Ar-Ruzz, 2011.

Usman, R. (2009). Produk dan Akad Perbankan Syariah di Indonesia. Bandung : Citra Aditya Bakti. 